Article

\title{
Exploring Rice Root Microbiome; The Variation, Specialization and Interaction of Bacteria and Fungi In Six Tropic Savanna Regions in Ghana
}

\author{
Makoto Kanasugi ${ }^{1}$, Elsie Sarkodee-Addo ${ }^{2}$, Richard Ansong Omari ${ }^{3,4}$, \\ Khondoker Mohammad Golam Dastogeer ${ }^{5,6} \mathbb{C}^{\circ}$, Yoshiharu Fujii ${ }^{2,6} \mathbb{C}^{\circ}$, \\ Samuel Oppong Abebrese ${ }^{7}\left(\mathbb{D}\right.$, Ralph Bam ${ }^{8}$, Stella Asuming-Brempong ${ }^{9}$ and Shin Okazaki ${ }^{2,6, *(1)}$ \\ 1 Graduate School of Bio-Applications and Systems Engineering, Tokyo University of Agriculture and \\ Technology, Nakacho 2-24-16, Koganei, Tokyo 184-8588, Japan; s158433s@st.go.tuat.ac.jp \\ 2 United Graduate School of Agricultural Science, Tokyo University of Agriculture and Technology, \\ Saiwaicho 3-5-8, Fuchu, Tokyo 183-8509, Japan; elsieaddo67@yahoo.com (E.S.-A.); yfujii@cc.tuat.ac.jp (Y.F.) \\ 3 Institute of Agriculture and Horticulture, Faculty of Life Science, Humboldt-University of Berlin, \\ Albrecht-Thaer-Weg 5, 14195 Berlin, Germany; talk2jafakingonline@gmail.com \\ 4 Leibniz Centre for Agricultural Landscape Research, Institute of Land Use Systems, Eberswalder Str. 84, \\ 15374 Müencheberg, Germany \\ 5 Graduate School of Plant Pathology, Bangladesh Agricultural University, Mymensingh 2202, Bangladesh; \\ dastogeer.ppath@bau.edu.bd \\ 6 Institute of Agriculture, Tokyo University of Agriculture and Technology, Saiwaicho 3-5-8, Fuchu, \\ Tokyo 183-8509, Japan \\ 7 CSIR-Savanna Agricultural Research Institute, P.O. Box 52, Tamale, Ghana; sam555oppa@yahoo.com \\ 8 CSIR-Crops Research Institute, P.O. Box 3785, Kumasi, Ghana; ralphbam@yahoo.com \\ 9 Department of Soil Science, University of Ghana, P.O. Box LG 25, Legon, Ghana; \\ sasuming-brempong@ug.edu.gh \\ * Correspondence: sokazaki@cc.tuat.ac.jp; Tel.: +81-42-367-5847
}

Received: 11 June 2020; Accepted: 11 July 2020; Published: 20 July 2020

\begin{abstract}
We investigated the root microbiomes of rice sampled from six major rice-producing regions in Ghana using Illumina MiSeq high-throughput amplicon sequencing analysis. The result showed that both bacterial and fungal community compositions were significantly varied across the regions. Bacterial communities were shaped predominantly by biotic factors, including root fungal diversity and abundance. In contrast, fungal communities were influenced by abiotic factors such as soil nitrate, total carbon and soil $\mathrm{pH}$. A negative correlation between the diversity and abundance of root fungi with soil nitrate $\left(\mathrm{NO}_{3}{ }^{-}\right)$level was observed. It suggested that there were direct and indirect effects of $\mathrm{NO}_{3}{ }^{-}$on the root-associated bacterial and fungal community composition. The gradient of soil nitrate from North to South parts of Ghana may influence the composition of rice root microbiome. Bacterial community composition was shaped by fungal diversity and abundance; whereas fungal community composition was shaped by bacterial abundance. It suggested the mutualistic interaction of bacteria and fungi at the community level in the rice root microbiome. Specific bacterial and fungal taxa were detected abundantly in the 'Northern' regions of Ghana, which were very low or absent from the samples of other regions. The analysis of indicator species suggested that an 'ecological specialization' may have occurred which enabled specific microbial taxa to adapt to the local environment, such as the low-nitrate condition in the Northern regions.
\end{abstract}

Keywords: Ghana; rice; root microbiome; community analysis; regional variation; nitrogen gradient; ecological specialization; bacterial-fungal interaction 


\section{Introduction}

The global human population is projected to reach eight to nine billion by 2050 [1]. With population growth, overexploitation of natural resources, including fossil fuels and nonrenewable raw materials has emerged as a great challenge for agriculture. Since the production of inorganic fertilizer relies heavily on nonrenewable resources [2-4], it is crucial to find renewable alternatives to chemical fertilizers, especially in developing countries [5]. Ghana, in West Africa, has attempted to promote rice production to feed its growing population [6], yet productivity has been low. The reported low rice yield across the nation is attributed to several factors. However, the major factors had been inadequate soil nutrient and inefficient fertilizer management due to low soil fertility, productivity remains low [7]. Therefore, it is urgent to find alternative, renewable ways to improve soil fertility and enhance plant's access to soil nutrients.

Root-associated microorganisms play a significant role in improving plant productivity [8]. Several root-associated bacteria and fungi are known to promote plant growth and increase plant tolerance to multiple environmental stresses $[9,10]$. Rhizobia are the best-known bacterial mutualistic symbionts, capable of fixing atmospheric nitrogen through nodulation in the roots of leguminous plants [11,12]. Arbuscular mycorrhizal fungi (AMF) are the most common mutualistic fungal symbionts, colonizing about $80 \%$ of land plants. They provide multiple benefits for host plants, including the supply of inorganic nutrients and enhanced disease resistance [13]. They promote the function and stability of ecosystems, including agricultural land [14]. Endophytic fungi (nonmycorrhizal fungal symbionts in roots) are capable of improving the environmental fitness of plant, including nutrient acquisition, enhancing disease resistance and drought tolerance [15-17]. In natural conditions, root-associated microorganisms coexist and interact as a root microbiome. Thus, it is vital to understand the whole microbiome to improve plant productivity and crop yield [18].

In general, the assembly of the host-associated microbiome, including the root-associated microbiome, is formed by colonization from regional microbial species, followed by host filtering [19]. In the terrestrial ecosystem, multiple environmental biotic and abiotic factors, are reported to affect the composition of the microbial species pool in soil [20]. Edwards et al. [21] conducted a wide-ranging investigation of the rice root-associated bacterial community in northern California, USA, and found regional variation. Further controlled experiments revealed the effect of environmental factors, including soil fertility [22] and soil salinity [23], on root-associated bacterial communities. Root fungal communities are found to be also determined by stochastic processes represented by geochemical differences, as well as by niche differences, including environmental factors [24]. However, no previous survey has focused on Ghanaian rice root microbiomes.

Evidence suggests that there are interactions between bacteria and fungi on many spatial scales, including that of plant roots, such as endosphere [25]. AMF and Rhizobium species partially share a symbiotic signaling pathway, the Common Symbiosis Pathway [26], which exerts a synergetic effect on the host plant, increasing nutrient acquisition [27]. Endophytic bacteria and fungi also interact on host rice roots to improve the host's physiological properties [28]. At the field-scale experiments, interactions between bacteria and fungi have been reported in several studies on leaf litter [29] and soil [30]. In the case of the root microbiome, Agler et al. [31] profiled the interactions of bacteria and fungi in the root community of Arabidopsis thaliana and found taxon-level interactions. However, field-scale understanding of the interactions between root-associated bacteria and fungi is still limited.

In Brazil, investigations of the functionality of soil microorganisms showed a substantial variation in the diversity and structure of bacterial communities. This was deemed as being due to geographic differences between tropical savanna climates [32]. Differences in function and environmental adaptability of root-associated microorganisms from different origins have also been reported [33,34]. From the findings, we infer that root-associated bacteria and fungi that are abundantly presenting in the specific region could have the potential for enhancing host adaptation and fitness to climatic variations.

Moreover, in a recent study [35] we reported that colonization intensity and taxonomic compositions of AMF in rice roots vary significantly among major rice-producing regions in Ghana, 
with available phosphorus found as the essential factor driving AMF community structures in rice roots. We found that certain environmental factors such as $\mathrm{C} / \mathrm{N}, \mathrm{NO}_{3}{ }^{-}$and importantly available phosphorus influenced community structuring of AMF in rice in Ghana. Our hypothesis was that similar to AMF other microbial community composition in the roots may also be different among these regions and shaped by the environmental variables. If that was true, which environmental factors were important in forming in the microbiome community composition among these regions. We did not come across any study that investigated the root microbiome of rice in those regions.

An understanding of the ecology of root-associated microorganisms is key to the development of sustainable rice production in Ghana. The hypotheses of our study were (1) rice root-associated microbiomes vary across the different regions, with local abiotic and biotic environmental factors involved in shaping the microbiome; (2) abundantly presenting bacterial and fungal in a different region could be key players in host rice productivity and (3) specific bacterial and fungal taxa may be correlated and interact in the rice root microbiome in Ghana. We used a high-throughput amplicon sequencing platform to reveal the structure and variation of bacterial and fungal communities. The goal of this study is to explore the possibility of applying root-associated microbiomes for sustainable rice production.

\section{Materials and Methods}

\subsection{Study Site}

Samples of soil and rice roots were collected from six Ghanaian rice-producing regions, including Upper West (UW), Upper East (U.), Northern (North), Ashanti (Ash), Brong-Ahafo (BA) and Volta (Vol) (Figure 1.). These selected regions are under three agroecological zones including; Guinea savannah, forest-savannah transitional and deciduous forest. The annual total precipitation means of 1063.7, 1161.3 and $1404.8 \mathrm{~mm}$ ranged within $0.0-257.4 \mathrm{~mm}, 4.4-1040 \mathrm{~mm}$ and $2.0-846.3 \mathrm{~mm}$ per month and with average annual temperatures of $28.3,27.0$ and $27^{\circ} \mathrm{C}$, ranged from $23.5-32.4{ }^{\circ} \mathrm{C}, 23.530 .4{ }^{\circ} \mathrm{C}$ and $26.0^{\circ} \mathrm{C}$, respectively $[36,37]$. Overall, we survey a total of 20 fields across the six regions.

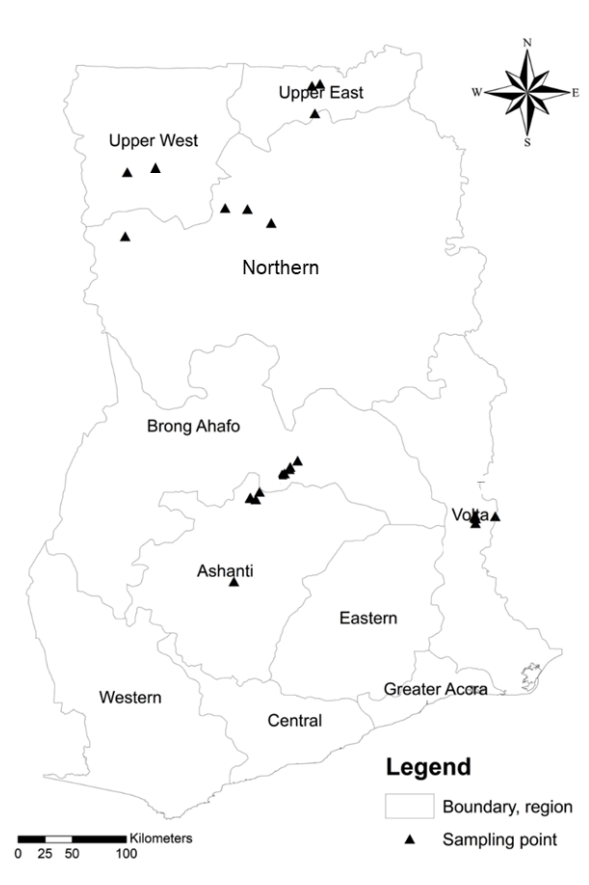

\begin{tabular}{|c|c|c|c|c|}
\hline \multirow{2}{*}{$\begin{array}{l}\text { Agro-ecological } \\
\text { zone }\end{array}$} & \multirow{2}{*}{ Region } & \multirow{2}{*}{ Location } & \multicolumn{2}{|c|}{ Geographic coordinate } \\
\hline & & & Latitude & Longitude \\
\hline \multirow{9}{*}{ Guinea savannah } & \multirow{2}{*}{ Upper West } & Dondoli & $010^{\circ} 03^{\prime} 00^{\prime \prime} \mathrm{N}$ & $002^{\circ} 29^{\prime \prime \prime} 00 \mathrm{~W}$ \\
\hline & & Bilibao & $010^{\circ} 17^{\prime} 06^{\prime \prime} \mathrm{N}$ & $001^{\circ} 57^{\prime} 36^{\prime \prime} \mathrm{W}$ \\
\hline & \multirow{3}{*}{ Upper East } & Yepalsi & $09^{\circ} 35^{\prime} 54.6^{\prime \prime} \mathrm{N}$ & $000^{\circ} 43^{\prime} 02.9^{\prime \prime} \mathrm{W}$ \\
\hline & & Kike & $010^{\circ} 47^{\prime} 00^{\prime \prime} \mathrm{N}$ & $000^{\circ} 51^{\prime} 00^{\prime \prime} \mathrm{W}$ \\
\hline & & Pwalugu & $10^{\circ} 35^{\prime} 50.1^{\prime \prime} \mathrm{N}$ & $000^{\circ} 50^{\prime} 59.0^{\prime \prime} \mathrm{W}$ \\
\hline & \multirow{4}{*}{ Northern } & $\begin{array}{l}\text { Gbrumani- } \\
\text { Tibogu }\end{array}$ & $09^{\circ} 41^{\prime} 40.4^{\prime \prime} \mathrm{N}$ & $001^{\circ} 12^{\prime} 77.3^{\prime \prime} \mathrm{W}$ \\
\hline & & Pagazaa & $09^{\circ} 22^{\prime} 23.5^{\prime \prime} \mathrm{N}$ & $000^{\circ} 42^{\prime} 49.5^{\prime \prime} \mathrm{W}$ \\
\hline & & Fuu & $09^{\circ} 15^{\prime} 15.0^{\prime \prime} \mathrm{N}$ & $000^{\circ} 37^{\prime} 45.0^{\prime \prime} \mathrm{W}$ \\
\hline & & Ngbanung & $09^{\circ} 28^{\prime} 31.0^{\prime \prime} \mathrm{N}$ & $001^{\circ} 01^{\prime} 90.0^{\prime \prime} \mathrm{W}$ \\
\hline \multirow{4}{*}{ Transitional zone } & \multirow{4}{*}{ Brong-Ahafo } & $\begin{array}{c}\text { Fante } \\
\text { Newtown }\end{array}$ & $07^{\circ} 36^{\prime} 50.6^{\prime \prime} \mathrm{N}$ & $001^{\circ} 60^{\prime} 41.0^{\prime \prime} \mathrm{W}$ \\
\hline & & Abour & $07^{\circ} 36^{\prime} 18.3^{\prime \prime} \mathrm{N}$ & $001^{\circ} 07^{\prime} 53.4^{\prime \prime} \mathrm{W}$ \\
\hline & & Mempeasem & $07^{\circ} 15^{\prime} 29.6^{\prime \prime} \mathrm{N}$ & $000^{\circ} 38^{\prime} 16.1^{\prime \prime E}$ \\
\hline & & Jato-Zongo & $07^{\circ} 40^{\prime} 02.5^{\prime \prime} \mathrm{N}$ & $001^{\circ} 03^{\prime} 52.4^{\prime \prime} \mathrm{W}$ \\
\hline \multirow{7}{*}{ Deciduous forest } & \multirow{4}{*}{ Ashanti } & Aframso & $0070375 N$ & $0010367 \mathrm{~W}$ \\
\hline & & Hiawoanwu & $07^{\circ} 27^{\prime} 41.3^{\prime \prime} \mathrm{N}$ & $001^{\circ} 19^{\prime} 05.5^{\prime \prime} \mathrm{W}$ \\
\hline & & Darko farms & $07^{\circ} 24^{\prime} 50.6^{\prime \prime} \mathrm{N}$ & $001^{\circ} 23^{\prime} 44.2^{\prime \prime} \mathrm{W}$ \\
\hline & & Ejura farms & $07^{\circ} 24^{\prime} 29.6^{\prime \prime} \mathrm{N}$ & $001^{\circ} 23^{\prime} 48.4^{\prime \prime} \mathrm{W}$ \\
\hline & \multirow{3}{*}{ Volta } & Gbefi & $07^{\circ} 00^{\prime} 13.3^{\prime \prime} \mathrm{N}$ & $000^{\circ} 20^{\prime} 08.6^{\prime \prime} \mathrm{E}$ \\
\hline & & Nywie-antokor & $07^{\circ} 26^{\prime} 07.0^{\prime \prime} \mathrm{N}$ & $000^{\circ} 25^{\prime} 20.5^{\prime \prime} \mathrm{E}$ \\
\hline & & Peacebee & $07^{\circ} 30^{\prime} 41.0^{\prime \prime} \mathrm{N}$ & $000^{\circ} 28^{\prime} 18.2^{\prime \prime E}$ \\
\hline
\end{tabular}

Figure 1. Sampling sites in rice cultivated fields of Ghana. The map shows 20 sampling areas marked with black triangles among six different regions under three agroecological zones of Ghana. 


\subsection{Root and Soil Sampling}

Healthy rice plants (cv. Jasmine85, commonly cultivated in Ghana) in their vegetative stage (thus maximum tillering), at an average height of about $55 \mathrm{~cm}$ (BBCH code, identifying phenologically development stages of crop plants: 29, maximum tillering detected), were collected randomly from eight different spots within each cultivated field were sampled. Upon sampling, rice roots were detached and washed gently with tap water to remove soil debris. Cleaned roots from the same field were mixed and dried by pressing with absorbent tissue paper. Soil $(0-15 \mathrm{~cm}$ depth) on the other hand, were collected randomly from eight different core spots within each sampling field and mixed as a sample. Sampled rice roots and soil were transferred to the laboratory in an icebox and stored at $-80^{\circ} \mathrm{C}$ until further use. In the laboratory, soil samples were dried at room temperature (approximately $25^{\circ} \mathrm{C}$ ) and sieved with $2 \mathrm{~mm}$ mesh to remove all other foreign materials. Samples were then stored at $5{ }^{\circ} \mathrm{C}$ until analyzed.

\subsection{Soil Property Analysis}

As soil properties, $\mathrm{pH}$, soil moisture, total carbon (TC), total nitrogen (TN), and the soil carbon-nitrogen ratio $(\mathrm{C} / \mathrm{N})$ were measured by the standard protocols for tropical soils [38]. The available phosphorus was determined by the Truog-soluble method extracted with sulfuric acid and ammonium sulfate $\left(\left(\mathrm{NH}_{4}\right)_{2} \mathrm{SO}_{4}, \mathrm{pH} 3.0\right)$ solution. Ammonia $\left(\mathrm{NH}_{4}{ }^{+}\right)$and nitrate $\left(\mathrm{NO}_{3}{ }^{-}\right)$ were extracted from $10 \mathrm{~g}$ soil with $2-\mathrm{M} \mathrm{KCl}$ solution [39], and concentrations were determined by the continuous flow injection analysis method and the indophenol-blue colorimetric procedure, respectively [40]. The cation exchange capacity (CEC) was measured by the Schollenberger and Simon method [41].

\subsection{Root DNA Isolation and PCR}

A total of 20 rice root samples were frozen-crushed with liquid nitrogen using a sterilized pestle and mortar. Total DNA was extracted from $100 \mathrm{mg}$ of finely ground samples using the Dneasy Plant Mini kit (Qiagen, Hilden, Germany) following the manufacturer's recommendations, and was stored at $-20^{\circ} \mathrm{C}$.

The bacterial 16S rRNA V4 region was amplified using the primer pair 515f (5'GTGYCAGCMGCCGCGGTAA-3') and 806r (5'-GGACTACNVGGGTWTCTAAT-3') described by Walters et al. [42] with AmpliTaq Gold DNA. Polymerase (Applied Biosystems). PCR was performed with a master mix in a $12.5-\mu \mathrm{L}$ reaction mixture with $0.0625 \mu \mathrm{L}$ polymerase, $5 \mathrm{pmol}$ of each barcoded primer (a unique combination for each sample), $2 \mathrm{mM}$ dNTP and $2.5 \mathrm{ng}$ of template DNA. We ran an initial denaturation of $10 \mathrm{~min}$ at $95{ }^{\circ} \mathrm{C}$, then 25 cycles at $94{ }^{\circ} \mathrm{C}$ for $30 \mathrm{~s}, 60^{\circ} \mathrm{C}$ for $30 \mathrm{~s}$ and $72{ }^{\circ} \mathrm{C}$ for $1 \mathrm{~min}$, followed by a $72{ }^{\circ} \mathrm{C}$ for $9 \mathrm{~min}$ for a final extension. The fungal ITS2 region was amplified using the primer pair ITS7-f (5'-GTGAATCATCGAATCTTTG-3') described by Ihrmark et al. [43] and ITS4-r (5'-TCCTCCGCTTATTGATATGC-3') described by White et al. [44] with KOD DNA polymerase each) and a tenth of the products of the first PCR. We ran an initial denaturation of $10 \mathrm{~min}$ at $95^{\circ} \mathrm{C}$, then 8 cycles at $94{ }^{\circ} \mathrm{C}$ for $30 \mathrm{~s}, 60^{\circ} \mathrm{C}$ for $30 \mathrm{~s}$ and $72{ }^{\circ} \mathrm{C}$ for $1 \mathrm{~min}$, then at $72{ }^{\circ} \mathrm{C}$ for $9 \mathrm{~min}$ for a final extension. The PCR products were purified with FastGene Gel/PCR Extraction kit (Nippon Genetics Co., Japan) and sequenced using Illumina MiSeq high-throughput sequencing.

\subsection{Statistical Analysis}

High-quality sequences were clustered into operational taxonomic units (out) with $97 \%$ similarity by QIIME software and taxa were assigned by BLAST search in GenBank. The resultant microbial OTUs were primarily analyzed with $R$ version 3.6.1 [45]. As with the microbial $\alpha$-diversity index, Shannon-Wiener and Simpson indices were calculated with the diversity() function in vegan. Chao richness was calculated with the chaorichness() function in the iNEXT software package [46]. Correlations between bacterial and fungal community composition and abiotic and biotic environmental 
factors were predicted by the envfit() function in vegan. Pearson's correlation coefficients were calculated using the ggscatter() function in $\mathrm{R}$ package ggpubr [47]. Community analyses were performed with the package vegan [48]. The OTUs with $<10$ read counts were removed. Prior to community analyses, all samples were normalized to 6000- and 7500-read counts for bacteria and fungi, respectively, due to their minimum read counts among samples (7812 for bacteria and 7983 for fungi), by random subsampling without replacement using the function rarefy() in vegan. Microbiomes in six regions were visualized by nonmetric dimensional scaling (NMDS) based on the Bray-Curtis dissimilarity index using the vegdist() function in vegan. Root-associated microbial community composition differences were tested by Permutational analysis of variance (PermANOVA) with the adonis() function and analysis of similarity (ANOISM) with the anosim() function in vegan.

Regionally more abundantly presenting, root-associated microbial indicator OTUs were identified by the mulipatt() function in the R package indicspecies [49] and clustered into six groups, UW, UE, North, Ash, BA and Vol; and into two groups, North Region (UW, UE, North) and southern region (Ash, BA Vol), independently based on abundance. In the indicator analysis, we only focused on the OTUs with $>500$ reads as common OTU, and the OTUs with $<500$ reads were removed as rare OTUs [50]. From common OTUs, OTUs with relative abundance of $<0.2 \%$ were also moved as low frequent taxa.

Cooccurrence network analysis was conducted using the CoNet method [51], using a multiple ensemble correlation (row_minocc filter $=20$ ). Five similarity measures were calculated: Bray-Curtis and Kullback-Leibler nonparametric dissimilarity indices, mutual information (MI) similarities and Pearson and Spearman correlation coefficients. Distribution of all pairwise scores between OTUs was computed for all six regions to enrich the network with OTU. nodes. Based on OTU distributions, initial thresholds were selected such that the initial network contained 1000 positive and 1000 negative edges, consistent across all five correlation measures. For each measure and each edge, 1000 renormalized permutation and bootstrap scores were generated [52,53]. Eventually, the cooccurrence network model was displayed by Cytoscape version 3.7.2.

\section{Results}

Soil properties of each sampling site are shown in Table 1. We found significant variations in those soil properties. Remarkably, we found the gradient of $\mathrm{NO}_{3}{ }^{-}$content from the Northern regions (UW, UE, North) to the South regions (BA, Ash, Vol) of Ghana.

After quality filtering and chimera removal, Illumina MiSeq high-throughput paired-end sequencing yielded of a total 4,400,432 sequences from the bacterial 16S V4 region and 3,401,411 from the fungal ITS region, from 20 samples each. After the removal of the nontarget taxa, we obtained 1,171,062 reads assigned as bacteria and 1,947,129 reads assigned as fungi. A total of 36,956 bacterial OTUs and 7101 fungal OTUs were obtained. As bacterial and fungal taxa, 54 and 12 phyla (including subphylum Glomeromycotina: former phylum Glomeromycota), 149 and 48 classes, 242 and 126 orders, 313 and 279 families, 531 and 562 genera, 24 and 639 species were observed in whole samples, respectively. After removal of low read count, OTUs with $<10$ read counts, rarefaction curves were predicted for both $16 \mathrm{~S}$ and ITS (Figure S1). 
Table 1. Variations of chemical and physical properties of soil samples from each sampling site in six different regions in Ghana.

\begin{tabular}{|c|c|c|c|c|c|c|c|c|c|}
\hline Site & Region & $\mathrm{pH}$ & Moisture & $\mathrm{NO}_{3}{ }^{-}$ & $\mathbf{P}$ & TC & TN & $\mathrm{CN}$ & C.E.C. \\
\hline Don & UW & $4.70 \pm 0.20 \mathrm{~b}$ & $7.000 \pm 0.655 \mathrm{k}$ & $25.77 \pm 1.28 \mathrm{i}$ & $0.3603 \pm 0.1107 \mathrm{gh}$ & $5.216 \pm 0.058 \mathrm{k}$ & $0.2633 \pm 0.0042 \mathrm{k}$ & $10.39 \pm 0.011$ & $5.466 \pm 0.042 n$ \\
\hline Bib & UW & $5.10 \pm 0.24 \mathrm{ab}$ & $13.14 \pm 1.74 \mathrm{i}$ & $44.20 \pm 1.14 \mathrm{~h}$ & $0.2560 \pm 0.0307 \mathrm{gh}$ & $6.084 \pm 0.039 \mathrm{k}$ & $0.6703 \pm 0.8110 \mathrm{i}$ & $11.69 \pm 0.01 \mathrm{~h}$ & $2.5770 .291 \mathrm{~m}$ \\
\hline Yep & UE & $5.00 \pm 0.16 \mathrm{ab}$ & $13.22 \pm 1.15 \mathrm{e}$ & $58.25 \pm 0.35 \mathrm{~g}$ & $0.1520 \pm 0.0272 \mathrm{~h}$ & $12.90 \pm 0.01 \mathrm{~h}$ & $2.097 \pm 0.011 \mathrm{e}$ & $15.08 \pm 0.01 \mathrm{a}$ & $14.76 \pm 0.05 \mathrm{~h}$ \\
\hline Kike & UE & $5.10 \pm 0.10 \mathrm{ab}$ & $11.66 \pm 0.65 \mathrm{~h}$ & $67.78 \pm 1.07 \mathrm{f}$ & $0.5370 \pm 0.0450 \mathrm{~g}$ & $13.09 \pm 0.03 \mathrm{~h}$ & $1.424 \pm 0.014 \mathrm{~h}$ & $13.02 \pm 0.01 \mathrm{c}$ & $14.56 \pm 0.11 \mathrm{~h}$ \\
\hline $\mathrm{Pw}$ & UE & $4.80 \pm 0.12 b$ & $14.60 \pm 1.21 \mathrm{~d}$ & $13.27 \pm 0.34 j$ & $1.221 \pm 0.121 \mathrm{~d}$ & $12.08 \pm 0.03 \mathrm{~h}$ & $2.500 \pm 0.101 d$ & $12.37 \pm 0.02 \mathrm{f}$ & $10.87 \pm 0.06 \mathrm{k}$ \\
\hline GT & NO & $4.70 \pm 0.20 b$ & $18.62 \pm 0.69 \mathrm{jk}$ & $24.89 \pm 0.57 \mathrm{i}$ & $2.146 \pm 0.054 \mathrm{~b}$ & $5.837 \pm 0.029 \mathrm{k}$ & $0.3593 \pm 0.0149 \mathrm{jk}$ & $9.840 \pm 0.021 \mathrm{n}$ & 9.9170 .1211 \\
\hline PAGA & NO & $5.10 \pm 0.10 \mathrm{ab}$ & $8.440 \pm 0.287 \mathrm{jk}$ & $24.22 \pm 0.98 \mathrm{i}$ & $4.602 \pm 0.090 \mathrm{a}$ & $8.833 \pm 0.028 j$ & $0.3510 \pm 0.0045 \mathrm{jk}$ & $9.337 \pm 0.026 \mathrm{p}$ & $12.45 \pm 0.09 \mathrm{i}$ \\
\hline FUU & NO & $4.70 \pm 0.20 \mathrm{~b}$ & $15.40 \pm 0.49 \mathrm{gh}$ & $26.52 \pm 1.29 \mathrm{i}$ & $1.183 \pm 0.033 \mathrm{~d}$ & $10.84 \pm 0.059 \mathrm{i}$ & $1.446 \pm 0.003 \mathrm{gh}$ & $10.61 \pm 0.02 \mathrm{k}$ & $11.73 \pm 0.07 j$ \\
\hline $\mathrm{Ngb} 2$ & NO & $5.00 \pm 0.10 \mathrm{ab}$ & $9.280 \pm 0.591 \mathrm{j}$ & $44.79 \pm 0.63 \mathrm{~h}$ & $1.633 \pm 0.036 c$ & $7.789 \pm 0.055 j$ & $0.4733 \pm 0.0244 j$ & $9.517 \pm 0.017^{\circ}$ & $10.79 \pm 0.08 \mathrm{k}$ \\
\hline Aframso & Ash & $5.80 \pm 0.16 a$ & $15.58 \pm 0.99 \mathrm{~h}$ & $106.6 \pm 2.0 \mathrm{~d}$ & $1.017 \pm 0.027 \mathrm{de}$ & $28.36 \pm 0.04 d$ & $1.374 \pm 0.014 \mathrm{~h}$ & $12.89 \pm 0.02 \mathrm{~d}$ & $22.43 \pm 0.08 \mathrm{~d}$ \\
\hline Hia & Ash & $5.00 \pm 0.16 a b$ & $23.24 \pm 1.89 \mathrm{~cd}$ & $126.6 \pm 0.7 \mathrm{~b}$ & $0.2540 \pm 0.146 \mathrm{gh}$ & $29.64 \pm 0.03 c$ & $2.638 \pm 0.025 \mathrm{~cd}$ & $10.85 \pm 0.03 j$ & $20.84 \pm 0.09 e$ \\
\hline Dar & Ash & $5.00 \pm 0.16 a b$ & $10.82 \pm 1.21 \mathrm{f}$ & $96.50 \pm 2.32 \mathrm{e}$ & $0.7487 \pm 0.0373 \mathrm{ef}$ & $24.84 \pm 0.04 \mathrm{e}$ & $1.839 \pm 0.025 f$ & $10.17 \pm 0.03 \mathrm{~m}$ & $22.94 \pm 0.03 \mathrm{~d}$ \\
\hline Ejura & Ash & $5.30 \pm 0.3 a b$ & $9.840 \pm 0.52 \mathrm{~g}$ & $148.8 \pm 1.04 a$ & $0.8963 \pm 0.0103$ de & $25.87 \pm 0.06 \mathrm{e}$ & $1.608 \pm 0.037 \mathrm{~g}$ & $11.81 \pm 0.01 \mathrm{~h}$ & $22.96 \pm 0.04 \mathrm{~d}$ \\
\hline FanteN & BA & $5.10 \pm 0.10 \mathrm{ab}$ & $17.22 \pm 1.02 \mathrm{e}$ & $129.5 \pm 0.27 \mathrm{~b}$ & $0.5313 \pm 0.0218 \mathrm{fg}$ & $20.23 \pm 0.04 \mathrm{f}$ & $2.191 \pm 0.020 \mathrm{e}$ & $12.19 \pm 0.02 \mathrm{~g}$ & $15.54 \pm 0.17 \mathrm{~g}$ \\
\hline Abour & BA & $5.50 \pm 0.16 \mathrm{ab}$ & $6.784 \pm 0.54 c$ & $126.7 \pm 1.87 \mathrm{~b}$ & $0.5093 \pm 0.0124 \mathrm{fg}$ & $17.69 \pm 1.01 \mathrm{~g}$ & $2.715 \pm 0.043 c$ & $12.88 \pm 0.004 \mathrm{~d}$ & $14.45 \pm 0.03 \mathrm{~h}$ \\
\hline Mem & BA & $5.60 \pm 0.10 \mathrm{ab}$ & $11.88 \pm 0.91 \mathrm{a}$ & $146.9 \pm 0.7 \mathrm{a}$ & $0.4500 \pm 0.0271 \mathrm{fgh}$ & $25.93 \pm 0.03 \mathrm{e}$ & $3.917 \pm 0.010 \mathrm{a}$ & $12.66 \pm 0.004 \mathrm{e}$ & $16.85 \pm 0.03 \mathrm{f}$ \\
\hline Jato & BA & $5.00 \pm 0.16 \mathrm{ab}$ & $16.80 \pm 2.71 \mathrm{f}$ & $149.0 \pm 0.4 a$ & $1.072 \pm 0.042 \mathrm{de}$ & $24.86 \pm 0.07 \mathrm{e}$ & $1.845 \pm 0.029 \mathrm{f}$ & $11.63 \pm 0.02 \mathrm{i}$ & $15.95 \pm 0.03 \mathrm{~g}$ \\
\hline Gbe & Vol & $5.60 \pm 0.24 \mathrm{ab}$ & $13.40 \pm 1.13 \mathrm{a}$ & $126.9 \pm 2.0 \mathrm{~b}$ & $0.5037 \pm 0.0088 \mathrm{fg}$ & $39.92 \pm 0.02 \mathrm{a}$ & $3.918 \pm 0.010 \mathrm{a}$ & $12.880 .01 \mathrm{~d}$ & $24.94 \pm 0.01 \mathrm{c}$ \\
\hline Ny1 & Vol & $5.10 \pm 0.10 \mathrm{ab}$ & $18.76 \pm 0.88 \mathrm{~b}$ & $108.3 \pm 0.8 \mathrm{~d}$ & $0.4027 \pm 0.0096 \mathrm{gh}$ & $38.44 \pm 0.02 \mathrm{~b}$ & $3.486 \pm 0.028 b$ & $13.97 \pm 0.01 \mathrm{~b}$ & $29.97 \pm 0.09 a$ \\
\hline Pea2 & Vol & $5.60 \pm 0.29 \mathrm{ab}$ & $19.60 \pm 0.32 \mathrm{e}$ & $118.9 \pm 0.8 c$ & $0.5177 \pm 0.0110 \mathrm{fg}$ & $38.31 \pm 0.02 b$ & $2.229 \pm 0.034 \mathrm{e}$ & $12.47 \pm 0.03 f$ & $27.55 \pm 0.05 b$ \\
\hline
\end{tabular}

Differences of each soil property were compared by ANOVA. Different alphabets stand for statistical differences in Turkey's test. UW—Upper West region, including Don, Bib; UE-Upper East region, including Yep, Kike, Pw; NO-Northern region, including GT, PAGA, FUU; Ngb; Ash—Ashanti region, including AframsoU, Hia, Dar, Ejura; BA—Brong-Ahafo, including FanteN, Abour, Mem, Jato; Vol—Volta region; including Gbe; Ny, Pea. 
Ordination analysis was performed, to investigate patterns of microbiome assemblages of rice roots, across the six locations. Two-dimensional nonmetric multidimensional scaling (NMDS), based on Bray-Curtis dissimilarity, did not show any noticeable pattern of variation of bacterial communities across the regions (Figure 2a). For fungal communities, we found that there were significant differences between the northern regions of Ghana (UW, UE, NO) and those from the southern regions (BA, Ash, Vol), as displayed by NMDS. plot (Figure 2b). In contrast, PermANOVA detected a significant difference in both root-associated bacterial and fungal communities, between the six regions $(P:<0.001$ and 0.0092 , respectively), albeit with a low pseudo- $F$ value (Table 2).

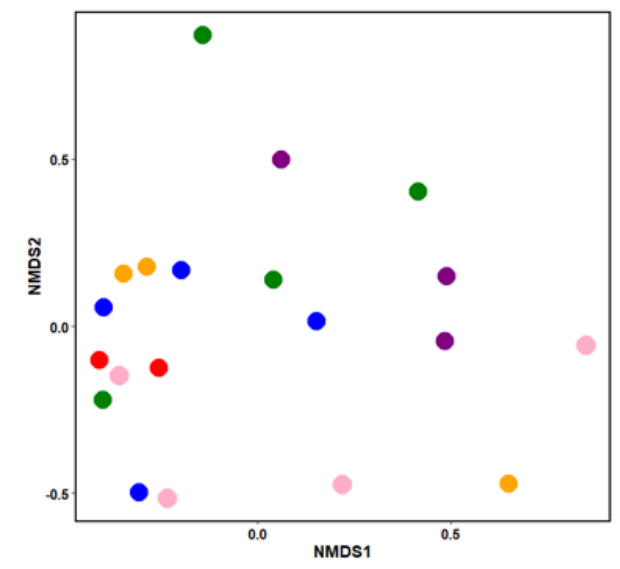

(a)

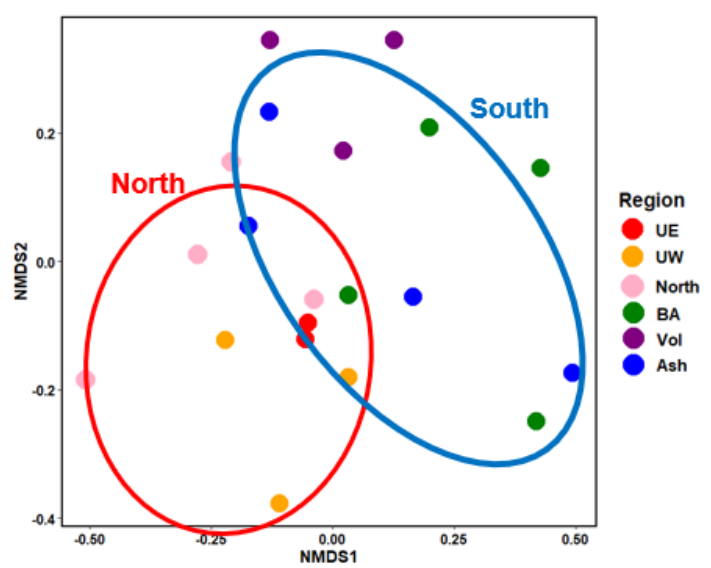

(b)

Figure 2. Nonmetric multidimensional scaling (NMDS) of Bray-Curtis pairwise dissimilarity of (a) bacterial and (b) fungal community. Regions coded by color. UW-Upper East region; UE-Upper East region; NO—Northern region; Ash-Ashanti region, including AframsoU, Hia, Dar and Ejura; BA-Brong-Ahafo, including FanteN, Abour and Mem, Jato; Vol—Volta region; including Gbe, Ny and Pea; Upper-North regions (UW, UE and NO); South-South regions (BA, Ash andVol).

Table 2. Difference between rice root-associated bacterial and fungal community composition among six different regions in Ghana.

\begin{tabular}{ccccc}
\hline \multirow{2}{*}{ Kingdom } & \multicolumn{2}{c}{ PermANOVA } & \multicolumn{2}{c}{ ANOSIM } \\
\cline { 2 - 5 } & Pseudo-F & $\boldsymbol{P}$ & $\mathbf{R}$ & $\boldsymbol{P}$ \\
\hline Bacteria & 2.436 & $<0.001$ & 0.2114 & 0.0338 \\
Fungi & 1.589 & 0.0092 & -0.0228 & 0.5786 \\
\hline
\end{tabular}

Bacterial and fungal community differences were tested by PermANOVA and ANOSIM after rarefying each OTU table to 6000 and 7500 reads, respectively.

We considered several biotic and abiotic factors to explain the variation in the microbiome composition of rice roots, across the locations studied (Table 3, Tables S4 and S5). Vector analysis revealed that assemblies of bacterial community composition were significantly correlated with one abiotic factor: soil moisture $(P=0.0405)$. The fungal diversity was also correlated with bacterial composition, evidenced by Shannon index $(P=0.0292)$ and Simpson index $(P=0.0404)$. Assemblies of fungal community composition were significantly correlated with four soil abiotic factors $(P<0.05)$ : $\mathrm{pH}(P=0.0104), \mathrm{NO}_{3}{ }^{-}$concentration $(P<0.001)$, total carbon $(\mathrm{TC}, P<0.001)$ and cation exchange capacity $(C E C, P=0.0226)$. Bacterial read number $(P=0.0251)$ was correlated with assemblies of fungal community composition. 
Table 3. Abiotic and biotic environmental variables involved in the assembly of rice root-associated bacterial and fungal community composition in six different regions in Ghana.

\begin{tabular}{|c|c|c|c|c|c|c|}
\hline Kingdom & Factor & Variable & NMDS1 & NMDS2 & r2 & $P$ \\
\hline \multirow{6}{*}{ Bacteria } & \multirow{2}{*}{ abiotic } & Moisture & 0.9773 & 0.2118 & 0.3112 & 0.0405 \\
\hline & & $\mathrm{TN}$ & 0.2311 & 0.9729 & 0.2428 & 0.0915 \\
\hline & \multirow{4}{*}{ biotic } & ReadFun & 0.7245 & -0.6893 & 0.4304 & 0.0078 \\
\hline & & ObsFun & 0.15572 & -0.9878 & 0.2625 & 0.0740 \\
\hline & & ShnFun & -0.8061 & -0.5918 & 0.3374 & 0.0292 \\
\hline & & SimFun & -0.7407 & -0.6718 & 0.3150 & 0.0404 \\
\hline \multirow{6}{*}{ Fungi } & \multirow{5}{*}{ abiotic } & $\mathrm{pH}$ & 0.45549 & 0.8903 & 0.4114 & 0.0104 \\
\hline & & $\mathrm{NO}_{3}^{-}$ & 0.7563 & 0.6543 & 0.5797 & $<0.001$ \\
\hline & & TC & 0.3870 & 0.9221 & 0.5601 & $<0.001$ \\
\hline & & $\mathrm{TN}$ & 0.6247 & 0.7809 & 0.2796 & 0.0629 \\
\hline & & CEC & 0.38942 & 0.92106 & 0.3546 & 0.0226 \\
\hline & biotic & ReadBac & -0.08821 & -0.9961 & 0.3546 & 0.0251 \\
\hline
\end{tabular}

Abiotic and biotic environmental factors involved in the assembly of bacterial and fungal community composition revealed by vector analysis. Bac—bacteria; Fun—fungi; Read—read counts; Shn—Shannon index; Sim—Simpson index; Read-read number; Obs—observed OTU number; TN—total nitrogen; TC — total carbon; CEC —cation exchange capacity. NMDS1 and NMDS2 stand for the axes in NMDS. (Nonmetric multidimensional scaling) plotting.

Further analysis of Pearson's correlation between abiotic and biotic environmental factors indicated that the concentration of soil $\mathrm{NO}_{3}{ }^{-}$significantly influenced fungal $\alpha$-diversity indices, including observed OTU number, fungal Chao richness and Shannon index, while total soil carbon influenced bacterial read number (Figure 3, Table S5).

Analysis of indicator species detected more abundantly presenting bacterial and fungal OTUs in the root-associated microbiome in 6 regions. Overall, the northern regions (UW, UE, NO) tended to harbor such bacterial and fungal OTUs in rice root-associated microbiome, to a greater extent than the southern regions (Ash, BA, Vol). For example, one bacterial OTU (Sporomusa sp. OTU_B4896) was abundantly presenting in three northern regions of Ghana; UW, UE and NO (Table S6). Among fungal communities, we found that one fungal OTU was abundantly present in the UW, UE and Northern regions and six OTUs were common to three regions (UW, UE, NO), but were absent from the southern regions (Table S7).

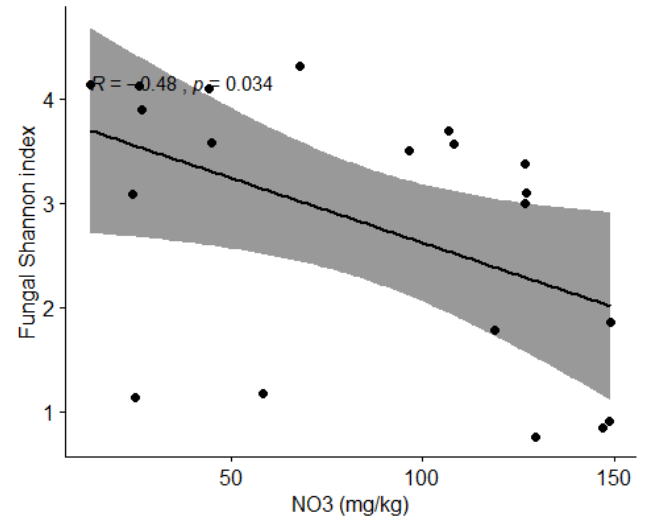

(a)

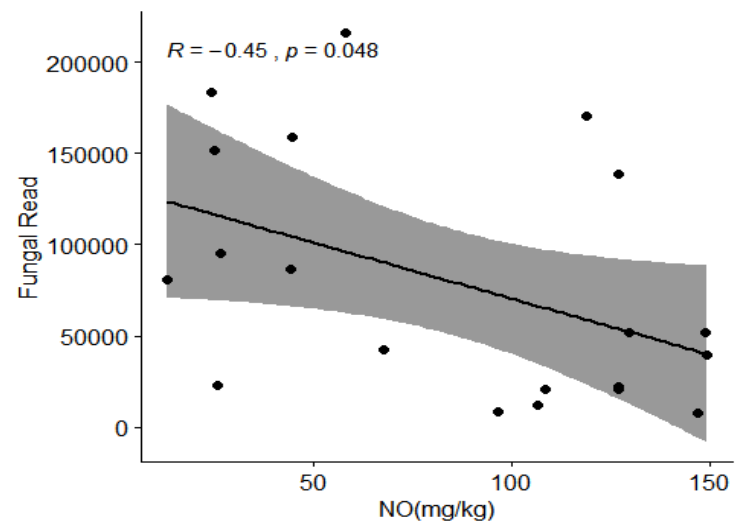

(b)

Figure 3. Cont. 


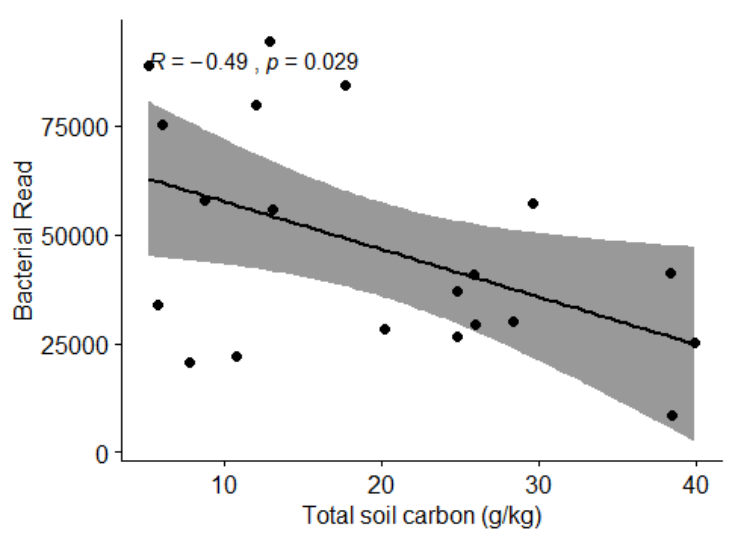

(c)

Figure 3. Correlation between abiotic and biotic environmental factors within six different regions in Ghana. Pearson's correlation coefficient was obtained between (a) soil $\mathrm{NO}_{3}{ }^{-}$concentration and fungal Shannon index, (b) soil $\mathrm{NO}_{3}{ }^{-}$concentration and fungal read number and (c) soil total carbon (TC) and bacterial read number (ReadBac).

Further analysis of indicator species detected root-associated bacterial and fungal OTUs abundantly presenting to the northern regions (UW, UE, NO) of Ghana (Tables 4 and 5). Among bacterial communities, we found seven OTUs abundantly present in the northern regions, five of which were taxa previously reported as endophytes, and one of them was a taxon reported as pathogenic (Table 4). Among fungal communities, we found 16 fungal OTUs abundantly present in the northern regions; six taxa were reported as endophytic, three taxa as pathogenic, and six taxa were reported as being both endophytes and pathogens (Table 5). We found no such bacterial and fungal OTUs in the southern regions of Ghana.

Cooccurrence network analysis disclosed potential interactions between root-associated bacterial and fungal species (Figure 4). We found a complex bacterial network, consisting of 64 OTUs, but only two fungal OTUs were associated with bacterial OTUs (Figure 4). Bacterial and fungal taxa correlated with each other were Kaistobacter sp. (OTU_B22284) and Mycosphaerella tassiana (OTU_F7631), Acinetobacter rhizosphaerae (OTU_B38216) and an unidentified Ascomycota (OTU_F3422), respectively. Fungal OTUs correlated each other were Mycosphaerella tassiana OTU_F7631 and an unidentified fungus OTU_F5419 and Cercospora jatrophiphila OTU_F9290 and Glomeraceae OTU_F7924. 
Table 4. Bacterial indicator OTUs detected in northern regions of Ghana and their characteristics on host plant.

\begin{tabular}{|c|c|c|c|c|c|c|c|}
\hline \multirow{2}{*}{ OTU.ID. } & \multicolumn{2}{|c|}{ Probability } & \multirow{2}{*}{ Indicator Value Index } & \multirow{2}{*}{$P$} & \multirow{2}{*}{ Characteristic } & \multirow{2}{*}{ Reference } & \multirow{2}{*}{ Host } \\
\hline & $\mathbf{A}$ & B & & & & & \\
\hline $\begin{array}{l}\text { Sporomusa_sp. } \\
\text { OTU_B4896 }\end{array}$ & 0.9971 & 1.0000 & 0.999 & 0.001 & Free living or unknown & [54] & \\
\hline $\begin{array}{l}\text { Aeromonadaceae } \\
\text { OTU_B18812 }\end{array}$ & 0.9760 & 1.0000 & 0.988 & 0.020 & Endophyte & {$[55]$} & rice \\
\hline $\begin{array}{l}\text { Clostridium sp. } \\
\text { OTU_B44691 }\end{array}$ & 0.9752 & 1.0000 & 0.988 & 0.011 & Endophyte & {$[56]$} & maiden silver grass \\
\hline $\begin{array}{c}\text { Micromonosporaceae } \\
\text { OTU_B6546 }\end{array}$ & 0.9312 & 1.0000 & 0.965 & 0.015 & Endophyte & [57] & Leguminous and actinorhizal plants \\
\hline $\begin{array}{c}\text { Pleomorphomonas sp. } \\
\text { OTU_B24241 }\end{array}$ & 0.9698 & 0.8889 & 0.928 & 0.012 & Endophyte & {$[58]$} & rice \\
\hline $\begin{array}{l}\text { Achromobacter sp. } \\
\text { OTU_B36942 }\end{array}$ & 0.9506 & 0.8889 & 0.919 & 0.046 & Endophyte & [59] & wheat \\
\hline $\begin{array}{l}\text { Xanthomonadaceae } \\
\text { OTU_B14074 }\end{array}$ & 0.7998 & 1.0000 & 0.894 & 0.032 & Endophyte and Pathogen & {$[60]$} & rice and other plants \\
\hline
\end{tabular}

Abundantly presenting bacterial indicator OTUs in North regions (UW, UE, NO) were revealed by indicator species analysis after removing low frequent OTUs (<500 reads, $0.2 \%$ sequence) from bacterial OTU tables. 
Table 5. Fungal indicator OTUs detected in northern regions of Ghana and their characteristics on host plant.

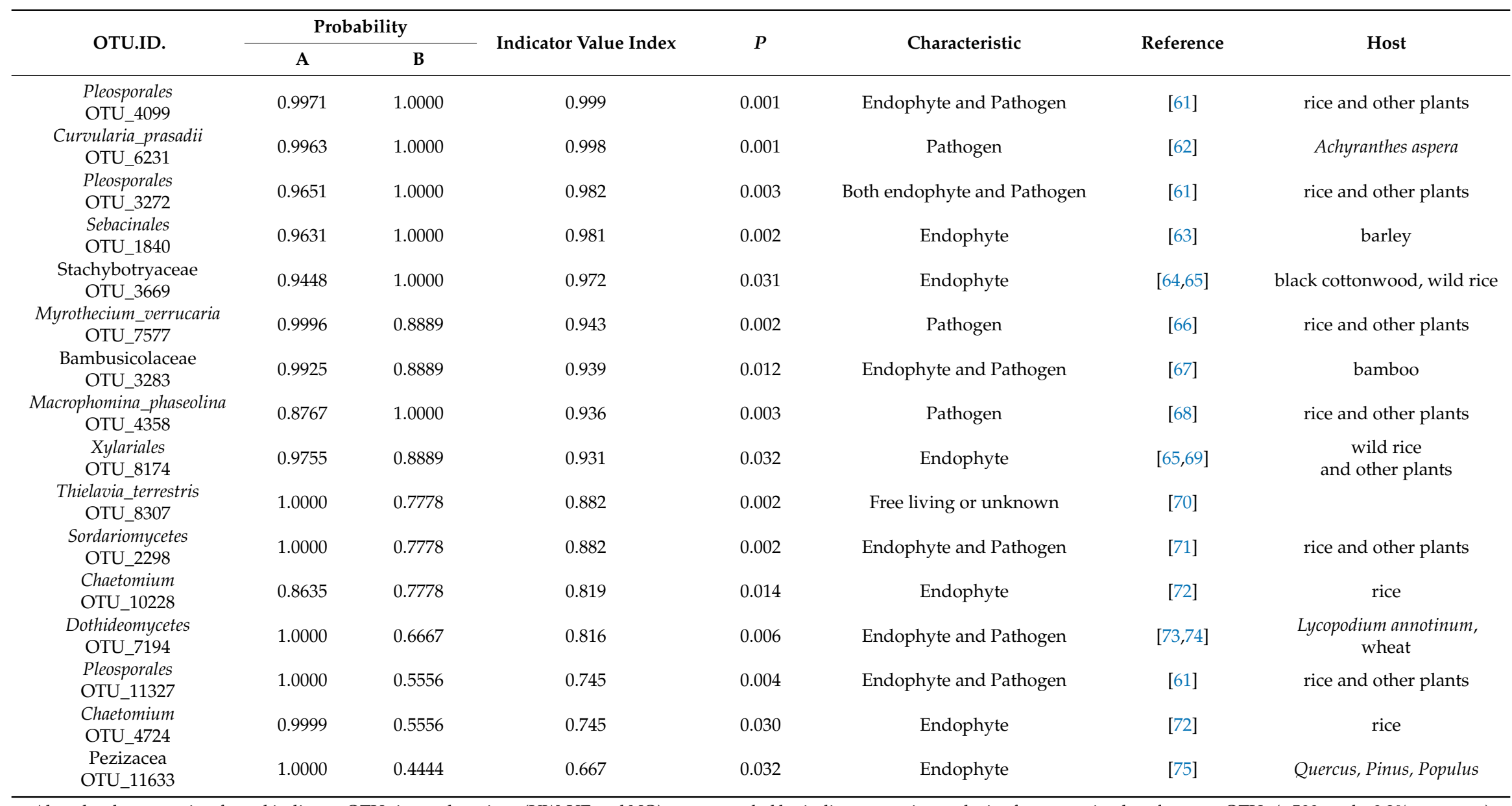

Abundantly presenting fungal indicator OTUs in north regions (UW, UE and NO) were revealed by indicator species analysis after removing low frequent OTUs (<500 reads, $0.2 \%$ sequence) from fungal OTU tables. 


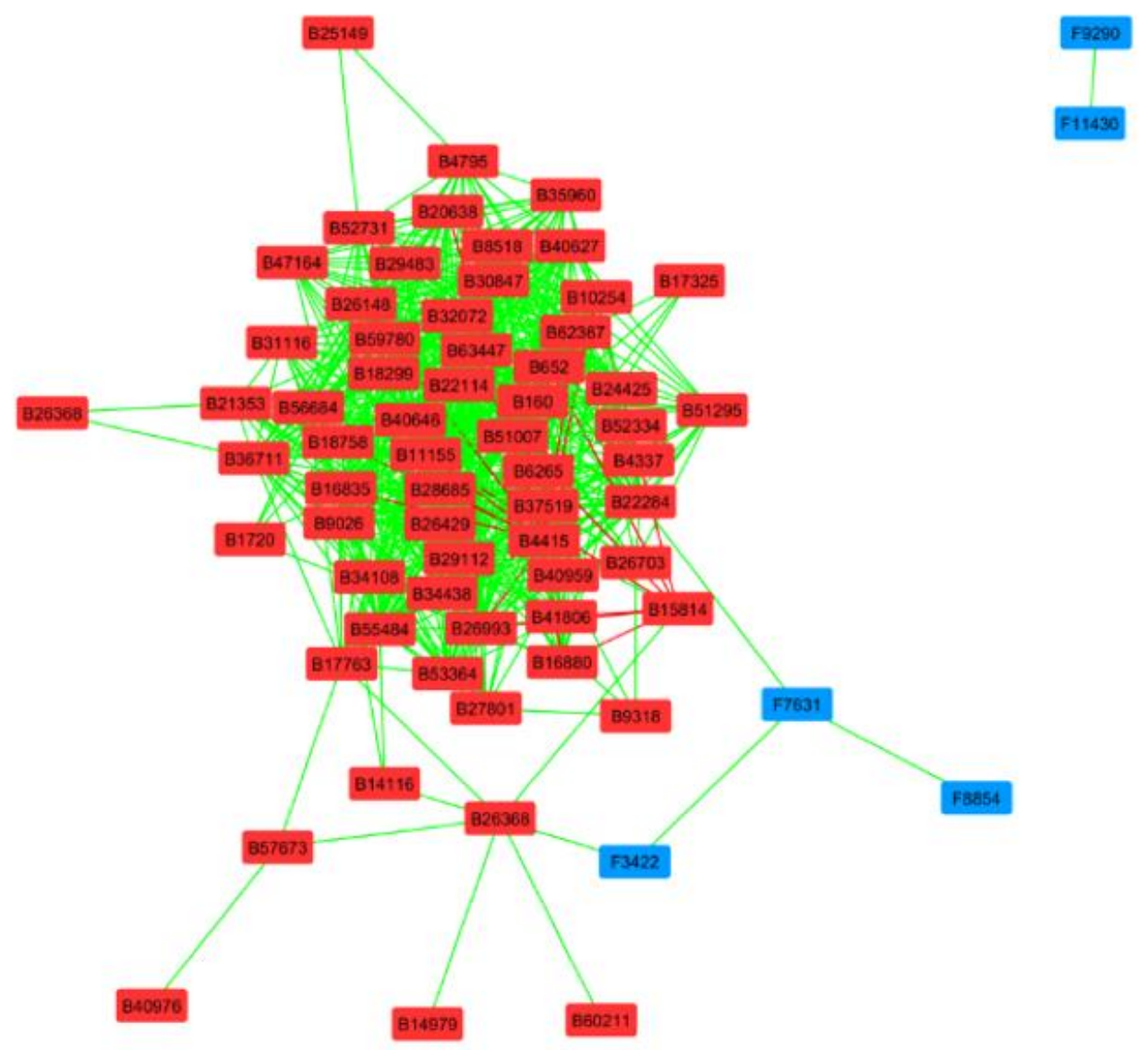

Figure 4. Cooccurrence network of bacterial and fungal OTUs within the rice root microbiome among six regions in Ghana. OTUs with low frequency ( $<500$ reads, $0.2 \%$ sequence) were removed from both bacterial and fungal OTU data. Each kingdom was coded by colors; bacteria with the red box and fungi with the blue box. Green lines show a positive correlation between OTUs, while the red lines show a negative correlation between OTUs.

\section{Discussion}

\subsection{Variations in Rice Root Microbiome Composition and the Influence of Environmental Factors.}

We tested hypothesis 1) that rice root-associated microbiomes vary across the different regions, with local abiotic and biotic environmental factors involved in shaping the microbiome. We did find a variation in root-associated microbiomes across the six regions. Both bacterial and fungal communities showed significant differences among regions, in PermANOVA. However, we also found low pseudo-F values: 2.436 and 1.586, respectively (Table 2), implying a low effect-size of regional differences on microbial community differences.

We detected abiotic and biotic environmental factors that influenced the assembly of rice root microbiomes (Table 3). Based on these results, a conceptual model was constructed to show the factors which shape the assembly of the rice root-associated microbiome in six regions of Ghana (Figure 5). Several abiotic factors: $\mathrm{NO}_{3}{ }^{-}, \mathrm{pH}, \mathrm{CEC}$, and TC were shown to shape the fungal community. Two biotic factors, root fungal diversity and root fundal read count as abundance seemed to shape the bacterial community. Moreover, soil $\mathrm{NO}_{3}{ }^{-}$concentration was significantly correlated with root-associated fungal diversity, which indicates that this factor directly affects the assembly of the fungal community and indirectly affects the root-associated bacterial community by altering root fungal $\alpha$-diversity. 


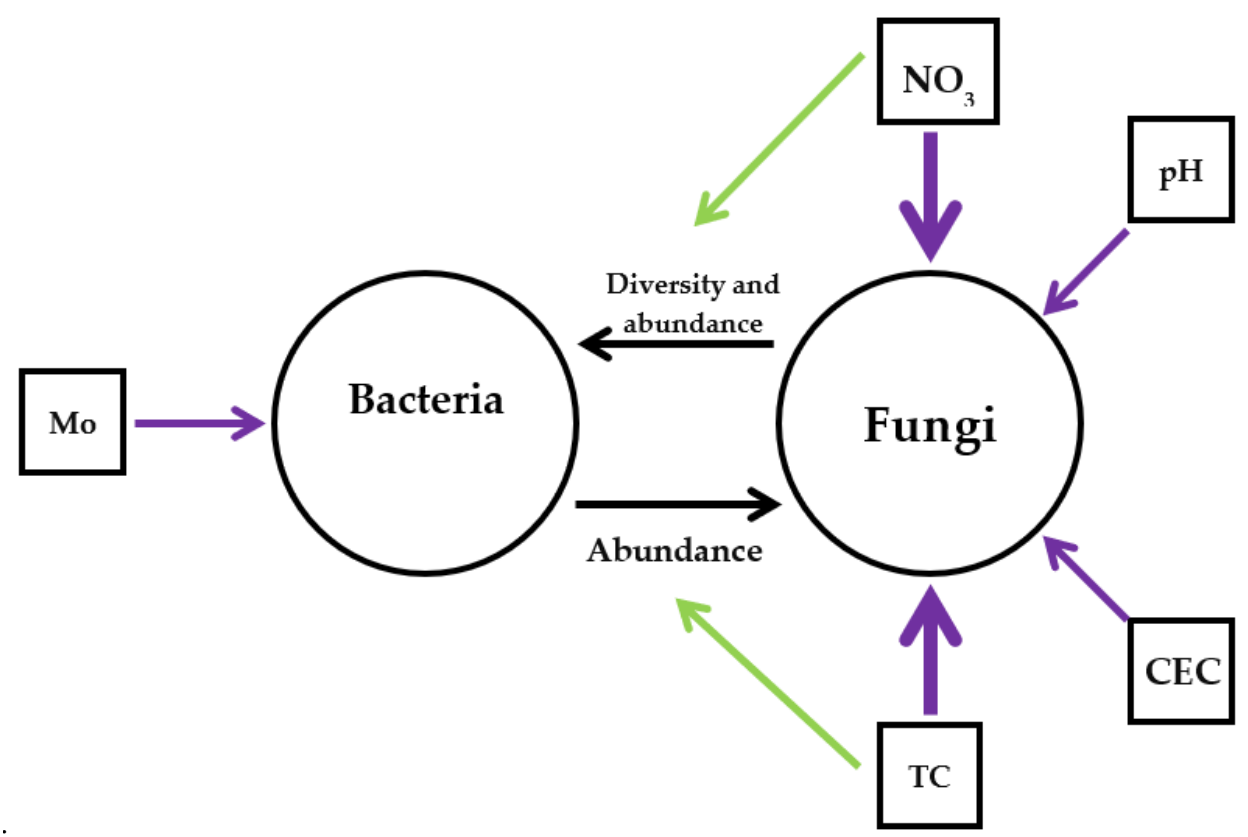

Figure 5. Conceptual model of factors that shape the assembly of rice root microbiome in six regions in Ghana. Model of bacterial and fungal community assembly was predicted based on the result of vector analysis (Tables S7 and S8; $P<0.05$ ). Thickness of arrow stands for statistical significance: $P<0.05$, $P<0.01, P<0.001$. Mo-moisture, CEC—cation exchange capacity; TC—-total carbon.

Nitrogen is the primary limiting nutrient in most terrestrial ecosystems, with $\mathrm{NO}_{3}{ }^{-}$as the form of nitrogen available to both plants and soil microorganisms [54]. In soil property analysis, we found a $\mathrm{NO}_{3}{ }^{-}$gradient from the northern to southern regions of Ghana (Table 1). Fierer et al. [55] found that microbial communities varied along a soil nitrogen gradient in field-based long-term nitrogen fertilization experiments in the US. Chen et al. [56] also conducted a field-based long-term nitrogen enrichment experiment in semiarid Mongolia and found a significant decrease in soil fungal and bacterial biomass along the nitrogen gradient. Furthermore, root-associated fungi, such as arbuscular mycorrhizal fungi and ectomycorrhizal fungi showed an alteration in community structures, with a decline in diversity and richness along the soil nitrogen gradient $[57,58]$. Our results support their findings that nitrogen enrichment significantly affects the structure and diversity of root-associated microbiomes. We assume that the $\mathrm{NO}_{3}{ }^{-}$gradient that we observed may be due to farmer's fertilizer management. The Southern regions which were considered in this study belong to the Transition and Deciduous Forest agroecological zones, which have two rainy seasons, with annual precipitation of 1161.3 and $1404.8 \mathrm{~mm}$, respectively. The studied regions in the north belong to the Savannah agroecological zone, which has only one rainy season, with an average rainfall of $1063.7 \mathrm{~mm}$ per year and a relatively low soil $\mathrm{NO}_{3}{ }^{-}$concentration [39]. Many farmers in the Southern regions, with better financial circumstances than those in the Northern regions, can also afford to apply chemical fertilizers to achieve higher yields [59].

The potential effect of soil $\mathrm{NO}_{3}{ }^{-}$enrichment on the assembly of root microbiome is due to the decrease in soil $\mathrm{pH}$ [60]. However, our soil property analysis showed a tendency toward lower soil pH in northern regions than in southern regions (Table 1). Therefore, we presume that other mechanisms may be involved in this phenomenon; influence of $\mathrm{NO}_{3}{ }^{-}$on rice root microbiome. In evolutionary history, plants have taken advantage of symbiotic relationships with microorganisms to enhance adaptability to multiple abiotic and biotic environmental stresses [61]. In the case of nitrogen deficiency, plants tend to change the composition and quantity of root exudates, potentially recruit beneficial microorganisms into their roots and discourage colonization by nonbeneficial microbes [62]. We hypothesize that such selection by the host may have influenced the assembly of rice root-associated microbes to adapt themselves to local $\mathrm{NO}_{3}{ }^{-}$conditions in six regions via unknown mechanisms. We also envisage that the 
model could be more complex in our field-based observational survey than in other studies mentioned above which had tightly controlled experimental designs. Further investigation is needed to reveal the intricate relationships between microbiome networks, the host, and environmental factors.

\subsection{Abundantly Presenting Bacterial and Fungal Taxa and Their Potential Functions in the Root-Associated Microbiome in the Six Regions}

We tested hypothesis 2 , that abundantly presenting bacterial and fungal in a different region could be key players in host rice productivity. We found that some bacterial and fungal OTUs were specific to the northern regions (UW, U., NO) harbor certain OTUs that are absent in the southern regions (BA, Ash, Vol). As mentioned above, the northern regions of Ghana belong to an agroecological zone called Guinea Savannah, and they are characterized by lower $\mathrm{pH}, \mathrm{NO}_{3}{ }^{-}, \mathrm{TC}, \mathrm{TN}$ and $\mathrm{CEC}$ (Table 1). The Guinea Savannah itself, including the northern regions, is characterized by higher temperatures than other zones (mean annual average, $28.3^{\circ} \mathrm{C}$ [36]). The bacterial and fungal indicator OTUs in these regions may have adapted to the environment and could be the candidate of Grinnell's ecological "specialist" [63]. Evidence of such specialization of microorganisms has also been reported elsewhere (e.g., [64].). They found evidence of the ecological specialization of heterotrophic bacteria in different nitrogen enrichment in stream sediment. However, previous studies did not report the specialization of root-associated microorganisms at the regional scale, so ours may be the first study to do so.

Some of the microbial OTUs abundantly present to the northern regions are known to be endophytes (e.g. Aeromonadaceae sp., Clostridium sp. Pleomorphomonas sp.) or pathogens (e.g. Xanthomonadaceae. OTU_B14074). The family Aeromonadaceae includes well-known pathogens of mammals, including humans [65], and others are also reported to colonize rice roots as endophytes [66], but their function in the rice host is not known. The genus Clostridium includes species that are capable of nitrogen fixation in the root of Miscanthus sinensis (Chinese silver grass) [67]. The genus Pleomorphomonas includes the species $P$. oryzae, capable of nitrogen fixation in rice roots [68]. The family Xanthomonadaceae includes two plant-pathogenic genera, Xanthomonas and Xylella [69], with Xanthomonas oryzae specific to rice [70].

Among the abundantly presenting fungal OTUs, one taxon has been reported as a rice endophyte, Chaetomium (OTU_F10228 and OTU_F4724). Another is both an endophyte and a pathogen in rice, Pleosporales (OTU_F4099, F3272 and F11327). Three have been identified as rice pathogens, Sordariomycetes. (OTU_F2298), Myrothecium verrucaria. (OTU_F7577) and Macrophomina phaseolina (OTU_F4358) (Table 5.). The genus Chaetomium includes the species C. globosum, capable of colonizing rice root and leaves and producing antifungal metabolites [71,72]. The genus Cochliobolus, which belongs to the order Pleosporales, is a well-studied pathogen of monocots with a wide range of hosts, including rice [73]. The class Sordariomycetes includes the species Magnaporthe grisea, which is a known cause of rice blast disease [74]. Myrothecium verrucaria and Macrophomina phaseolina are plant pathogens with a wide range of hosts, including rice [75,76].

Endophytes from these abundantly presenting microbial taxa could be key players for improving rice production in the northern regions of Ghana. The genus Pleomorphomonas, in particular, is expected to improve nitrogen availability for rice by nitrogen fixation. On the other hand, we also detected abundantly presenting bacterial and fungal pathogenic taxa that could be the cause of rice disease needing to be controlled in the northern regions. We expect the abundantly presenting fungal endophyte Chaetomium (OTU_F10228 and OTU_F4724) could antagonize these abundantly presenting pathogens in the northern regions by producing pharmacologically active metabolites [71]. Further functional investigation by isolation with pure culturing and in vitro scale experiments is necessary to assess the roles of those abundantly presenting taxa for host and adaptability to local environments.

\subsection{Potential Interactions Between Bacteria and Fungi in the Root Microbiome in Six Regions}

We tested hypothesis 3 , certain bacterial and fungal taxa may be correlated and interact in the rice root microbiome in Ghana. By vector analysis, we revealed the abiotic and biotic environmental factors 
involved in the assembly of the root-associated microbiome, with evidence for interactions between root-associated bacteria and fungi. Cooccurrence network analysis revealed potential interactions among bacterial and fungal OTUs in the root microbiome as a cooccurrence pattern. We found few cooccurrence patterns between bacterial and fungal OTUs. On the other hand, we found significant correlations between the assembly of bacterial and fungal community composition and their diversity indices (Table 3), hence, we assume that there are, potentially, interactions between bacteria and fungi at the community level within rice root-associated microbiomes in Ghana.

In general, bacteria and fungi share microhabitats in a variety of environments in which they interact with each other [77]. Such interaction has been widely studied, especially by in vitro scale studies [78,79], although our understanding of bacterial and fungal interaction is still limited at the field scale [78]. In the case of the root-associated microbiome, they share the plant root endosphere as a habitat and interact at both molecular and physiological levels, playing an important role in host plant productivity [80]. Few studies have focused on these potential interactions at the field scale.

It is thought that root-associated bacteria-fungus interaction is mediated by signal exchange with the host plant and competition for resources, including infection sites [81]. Our results suggest the potential interaction of root-associated bacteria and fungi at a community level, rather than at the level of OTUs. As mentioned previously, bacterial abundance affects fungal community assembly. Conversely, fungal diversity affects bacterial community assembly (Table 3 ). It has been reported that fungal and bacterial communities shape each other [82,83]. Singh et al. [82] revealed the potential effects of an arbuscular mycorrhizal fungal community on the root-associated bacterial community, although the inverse effect was not detected. Our study is consistent with their findings on the effect of root-associated fungi on bacteria at the community level. Furthermore, our results indicate that the bacterial community does affect the fungal community, suggestive of a mutualistic interaction in the root microbiome, at the community level. On the other hand, the more complex cooccurrence pattern of bacterial OTUs suggested that OTU level interaction occurs only within bacterial communities in the rice microbiome. This may be the first study to show evidence of mutualistic interaction of bacteria and fungi in a root microbiome at the community level. However, the nature and mechanisms of the interaction of rice root-associated bacteria and fungi are unclear.

\section{Conclusions}

In this study, we found that the structure of the rice root-associated bacterial and fungal community varied significantly between regions and that local environmental factors influence the assembly of these community compositions. The bacterial communities tended to be shaped by fungal $\alpha$-diversity and abundance, whereas the fungal communities tended to be shaped by abiotic factors, such as soil $\mathrm{NO}_{3}{ }^{-}$. The soil $\mathrm{NO}_{3}{ }^{-}$gradient from the North to South regions seems mostly responsible for the variation in the rice root microbiome directly and indirectly by affecting microbial diversity and abundance. We detected bacterial and fungal taxa abundantly present in the Northern regions, not in the Southern regions in Ghana reported as endophytic symbionts such as N-fixing bacteria. We suggest that those microbial traits may be candidates of ecological specialists, having adapted to a harsh, local environment and could be key players to improve host productivity. Finally, we uncovered potential interactions between rice root-associated bacteria and fungi at a community level; shaping each other at the community level, but not at OTU. However, the mechanisms shaping assembly of the rice root microbiome, the functions and role of the candidates of specialist microbial traits on the host plant, and their interactions are still uncertain. Further identification of functions, adaptabilities and interactions of those microbial traits by culturing method should be necessary. Overall, our study contributes to the further understanding of the ecology of the rice root microbiome and begins to explore its potential for the improvement of rice production in Ghana. 
Supplementary Materials: The following are available online at http://www.mdpi.com/2071-1050/12/14/5835/s1, Figure S1: Rarefaction curve, Table S1: Sample ID and sampling location, Table S2: $\alpha$-diversity index, Table S3: Correlation between bacterial community and environmental factors, Table S4: Correlation between fungal community and environmental factors, Table S5: Correlation between abiotic and biotic factors, Table S6: indicator bacterial OTU.s in six regions and their characteristics on host plant., Table S7: indicator Fungal OTUs in six regions and their characteristics on host plant.

Author Contributions: Conceptualization, M.K., E.S.-A. and S.O.; methodology, M.K., E.S.-A., S.O., R.A.O., S.O.A., R.B., S.A.-B.; validation, E.S.-A. and S.O.; formal analysis, M.K., E.S.-A. and S.O.; investigation, M.K., E. S-A. and S.O.; resources, S.O., Y.F., S.O.A, R.B., S.A.-B.; data curation M.K., E.S.-A., S.O., R.A.O., C.G.L. and K.M.G.D.; writing-M.K; writing-review and editing, E.S.-A., S.O., K.M.G.D.; visualization, M.K. and E.S.-A.; supervision, S.O.; project administration, S.O.; funding acquisition, S.O. All authors have read and agreed to the published version of the manuscript.

Funding: This study is funded by Japan Society for the Promotion of Science (no. 120199926).

Acknowledgments: We deeply appreciate the kind support of Allen Oppong and Beloved Mensah Dzomeku at the CSIR-Crops Research Institute for the experimental field survey in Ghana. We acknowledge the kind help and support of Alex Yeboah, at the Savannah Agriculture Research Institute, for the field survey and sampling in Ghana. We thank Michiko Yasuda of the Tokyo University of Agriculture and Technology for all kinds of help with PCR and sequencing, as well as advice and fruitful discussion about this study.

Conflicts of Interest: The authors declare no conflicts of interest.

\section{References}

1. Samir, K.; Luts, W. The human core of the shared socioeconomic pathways: Population scenarios by age, sex and level of education for all countries to 2100. Glob. Environ. Chang. 2014, 42, 181-192.

2. Tietenberg, T.; Lewis, L. Environmental and Natural Resource Economics, 10th ed.; Routledge: New York, NY, USA, 2016.

3. Crutzen, P.J.; Mosier, A.R.; Smith, K.A.; Winiwarter, W. N2O release from agro-biofuel production negates global warming reduction by replacing fossil fuels. Atmos Chem. Phys. 2008, 8, 389-395. [CrossRef]

4. Cordell, D.; Drangert, J.O.; White, S. The story of phosphorus: Global food security and food for thought. Glob. Environ. Chang. 2009, 19, 292-305. [CrossRef]

5. Raja, N. Biopesticides and Biofertilizers: Ecofriendly Sources for Sustainable Agriculture. J. Biofertil. Biopestic. 2013, 4, e112. [CrossRef]

6. Archibald, D.; Ashitey, E. Gain Report: Ghana. U.S.D.A. Foreign Agricultural Service. 2018. Available online: https://www.fas.usda.gov/data/ghana-grain-and-feed-annual-0 (accessed on 21 May 2019).

7. Buri, M.M.; Issaka, R.N.; Wakatsuki, T.; Kawano, N. Improving the productivity of lowland soils for rice cultivation in Ghana: The role of the 'Sawah' system. J. Soil Sci. 2012, 3, 56-62.

8. Tkacz, A.; Poole, P. Role of root microbiota in plant productivity. J. Exp. Bot. 2015, 66, 2167-2175. [CrossRef]

9. Hayat, R.; Ali, S.; Amara, U.; Khalid, R.; Ahmed, L. Soil beneficial bacteria and their role in plant growth promotion: A review. Ann. Microbiol. 2010, 60, 579-598. [CrossRef]

10. Barrow, J.R.; Lucero, M.E.; Reyes-Vera, I.; Havstad, K.M. Do symbiotic microbes have a role in regulating plant performance and response to stress? Commun. Integr. Biol. 2008, 1, 69-73. [CrossRef]

11. Van Rhijn, R.; Vanderleyden, J. The Rhizobium-Plant Symbiosis. Microbiol. Rev. 1995, 59, 124-142. [CrossRef]

12. Okazaki, S.; Kaneko, T.; Sato, S.; Saeki, K. Hijacking of leguminous nodulation signaling by the rhizobial type III secretion system. Proc. Natl. Acad. Sci. USA 2013, 110, 17131-17136. [CrossRef]

13. Smith, S.E.; Read, D.J. Mycorrhizal Symbiosis, 3rd ed.; Academic Press: London, UK, 2008.

14. Powell, J.R.; Rillig, M.C. Biodiversity of arbuscular mycorrhizal fungi and ecosystem Function. New Phytol. 2018, 220, 1059-1075. [CrossRef] [PubMed]

15. Hiruma, K.; Gerlach, N.; Sacristán, S.; Nakano, R.T.; Hacquard, S.; Kracher, B.; Neumann, U.; Ramírez, D.; Bucher, M.; O'Connell, R.J.; et al. Root Endophyte Colletotrichum tofieldiae Confers Plant Fitness Benefits that Are Phosphate Status Dependent. Cell 2016, 165, 464-474. [CrossRef] [PubMed]

16. Saunders, M.; Glenn, A.E.; Kohn, L.M. Exploring the evolutionary ecology of fungal endophytes in agricultural systems: Using functional traits to reveal mechanisms in community processes. Evol. Appl. 2010, 3, 525-537. [CrossRef] [PubMed] 
17. Dastogeer, K.M.G.; Wylie, S.J. Plant-Fungi Association: Role of fungal endophytes in improving plant tolerance to water stress. In Plant-Microbe Interactions in Agro-Ecological Perspectives; Springer: Singapore, 2017; pp. 143-159.

18. Lareen, A.; Burton, F.; Schäfer, P. Plant root-microbe communication in shaping root microbiomes. Plant Mol. Biol. 2016, 90, 575-587. [CrossRef] [PubMed]

19. Adair, L.K.; Douglas, A.E. Making a microbiome: The many determinants of host-associated microbial community composition. Curr. Opin. Microbiol. 2017, 35, 23-29. [CrossRef] [PubMed]

20. Nemergut, D.R.; Schmidt, S.K.; Fukami, T.; O’Neill, S.P.; Bilinski, T.M.; Stanish, L.F.; Joseph, E.; Knelman, J.E.; Darcy, J.L.; Lynch, R.C.; et al. Patterns and Processes of Microbial Community Assembly. Microbiol. Mol. Biol. Rev. 2013, 77, 342-356. [CrossRef]

21. Edwards, J.; Jonson, C.; Santos-Medellín, C.; Lurie, E.; Podishetty, N.K.; Bhatnagar, S.; Jonathan, A.; Eisen, J.A.; Sundaresan, V. Structure, variation, and assembly of the root-associated microbiomes of rice. Proc. Natl. Acad. Sci. USA 2015, 112, 911-920. [CrossRef]

22. Ikeda, S.; Sasaki, K.; Okubo, T.; Yamashita, A.; Terasawa, K.; Bao, Z.; Liu, D.; Watanabe, T.; Murase, J.; Asakawa, S.; et al. Low Nitrogen Fertilization Adapts Rice Root Microbiome to Low Nutrient Environment by Changing Biogeochemical Functions. Microbes Environ. 2011, 29, 50-59. [CrossRef]

23. Yaish, M.W.; Al-Lawati, A.; Jana, G.A.; Patankar, H.V.; Glick, B.R. Impact of Soil Salinity on the Structure of the Bacterial Endophytic Community Identified from the Roots of Caliph Medic (Medicago truncatula). PLoS ONE 2016, 11, e0159007. [CrossRef]

24. Beck, S.; Powell, J.R.; Drigo, B.; Cairney, J.W.G.; Anderson, I.C. The role of stochasticity differs in the assembly of soil- and root-associated fungal communities. Soil Biol. Biochem. 2015, 80, 18-25. [CrossRef]

25. Scherlach, K.; Graupner, K.; Hertweck, C. Molecular Bacteria-Fungi Interactions: Effects on Environment, Food, and Medicine. Annl. Rev. Microbial. 2013, 67, 375-397. [CrossRef] [PubMed]

26. Gutjahr, C.; Banba, M.; Croset, V.; An, K.; Miyao, A.; An, G.; Hirochika, H.; Imaizumi-Anraku, H.; Paszkowskia, U. Arbuscular Mycorrhiza-Specific Signaling in Rice Transcends the Common Symbiosis Signaling Pathway. Plant Cell 2009, 20, 2989-3005. [CrossRef] [PubMed]

27. Wang, X.; Pan, Q.; Chen, F.; Yan, X.; Liao, H. Effects of co-inoculation with arbuscular mycorrhizal fungi and rhizobia on soybean growth as related to root architecture and availability of N and P. Mycorrhiza 2011, 21, 173-181. [CrossRef] [PubMed]

28. Bandara, W.M.M.S.; Seneviratne, G.; Kulasooriya, S.A. Interactions among endophytic bacteria and fungi: Effects and potentials. J. Biosci. 2006, 3, 645-650. [CrossRef] [PubMed]

29. Purahong, W.; Wubet, T.; Lentendu, G.; Schloter, M.; Pecyna, M.J.; Kapturska, D.; Hofrichter, M.; Kruger, D.; Buscot, F. Life in leaf litter: Novel insights into community dynamics of bacteria and fungi during litter decomposition. Moleculer Ecol. 2016, 25, 4059-4074. [CrossRef]

30. De Menezes, A.B.; Prendergast-Miller, M.T.; Richardson, A.E.; Toscas, P.; Farrell, M.; Macdonald, L.M.; Baker, G.; Wark, T.; Thrall, P.H. Network analysis reveals that bacteria and fungi form modules that correlate independently with soil parameters. Enviol Microbiol. 2015, 17, 2677-2689. [CrossRef]

31. Agler, M.T.; Ruhe, J.; Kroll, S.; Morhenn, C.; Kim, S.T.; Weigel, D.; Kemen, E.M. Microbial Hub Taxa Link Host and Abiotic Factors to Plant Microbiome Variation. PLoS Biol. 2016, 14, e1002352. [CrossRef]

32. Pessoa-Filho, M.; Barreto, C.; dos Reis, C.C., Jr.; Fragoso, R.R.; Costa, F.S.; Mendes, L.D.C.; de Andrade, L.R.M. Microbiological functioning, diversity, and structure of bacterial communities in ultramafic soils from a tropical savanna. Antonie Van Leeuwenhoek 2015, 107, 935-949. [CrossRef]

33. Lau, J.A.; Lennon, J.T. Rapid responses of soil microorganisms improve plant fitness in novel environments. Proc. Natl. Acad. Sci. USA 2012, 109, 14058-14062. [CrossRef]

34. Zhang, H.; Cai, Y.; Li, X.; Christie, P.; Zhang, J.; Gai, J. Temperature-mediated phylogenetic assemblage of fungal communities and local adaptation in mycorrhizal symbioses. Enviol. Micol. Rep. 2019, 11, 215-226. [CrossRef]

35. Sarkodee-Addo, E.; Yasuda, M.; Lee, C.G.; Kanasugi, M.; Fujii, Y.; Omari, R.A.; Abebrese, S.O.; Bam, R.; Asuming-Brempong, S.; Dastogeer, K.M.G.; et al. Arbuscular Mycorrhizal Fungi Associated with Rice (Oryza sativa L.) in Ghana: Effect of Regional Locations and Soil Factors on Diversity and Community Assembly. Agronomy 2020, 10, 559. [CrossRef]

36. Aryee, J.N.A.; Amekudzi, L.K.; Quansah, E.; Klutse, N.A.B.; Atiah, W.A.; Yorke, C. Development of high spatial resolution rainfall data for Ghana. Int. J. Climatol. 2018, 38, 1201-1215. [CrossRef] 
37. Asare-Nuamah, P.; Botchway, E. Understanding climate variability and change: Analysis of temperature and rainfall across agroecological zones in Ghana. Heliyon 2019, 5, e02654. [CrossRef] [PubMed]

38. Anderson, J.M. Tropical Soil Biology and Fertility: A Handbook of Methods, 2nd ed.; Anderson, J.M., Ingram, J.S.I., Eds.; International Union of Biological Sciences: Paris, France; International Society of Soil Science: Vienna, Austria; CAB International: Wallingford, UK, 1993; ISBN 978-0-85198-821-4.

39. Truog, E. The Determination of the Readily Available Phosphorus of Soils 1. Agron. J. 1930, 22, 874-882. [CrossRef]

40. Parsons, T.R.; Maita, Y.; Lalli, C.M. Manual of Chemical and Biological Methods for Seawater Analysis; Pergamon Press: Oxford, UK, 1984; ISBN 978-0-08-030287-4.

41. Schollenberger, C.J.; Simon, R.H. Determination of Exchange Capacity and Exchangeable bases in soil-Ammonium acetate method. Soil Sci. 1945, 59, 13-24. [CrossRef]

42. Walters, W.; Hyde, E.R.; Berg-Lyons, D.; Ackermann, G.; Humphrey, G.; Parada, A.; Gilbert, J.A.; Jansson, J.K.; Caporaso, J.G.; Fuhrman, J.A.; et al. Improved bacterial 16S rRNA gene (V4 and V4-5) and fungal internal transcribed spacer marker gene primers for microbial community surveys. mSystems 2015, 1, e00009-e00015. [CrossRef]

43. Ihrmark, K.; Bödeker, I.T.M.; Cruz-Martinez, K.; Friberg, H.; Kubartova, A.; Schenck, J.; Strid, Y.; Stenlid, J.; Brandström-Durling, M.; Karina, E.; et al. New primers to amplify the fungal ITS2 region-Evaluation by 454-sequencing of artificial and natural communities. FEMS Microbiol. Ecol. 2012, 82, 666-677. [CrossRef]

44. White, T.J.; Bruns, T.; Lee, S.; Taylor, J. Amplification and direct sequencing of fungal ribosomal R.N.A. Genes for phylogenetics. In PCR Protocols: A Guide to Methods and Applications; Innis, M.A., Gelfand, D.H., Sninsky, J.J., White, T.J., Eds.; Academic Press: San Diego, CA, USA, 1990; pp. 315-322.

45. R Core Team. R: A Language and Environment for Statistical Computing. R Foundation for Statistical Computing. Vienna, Austria. Available online: https://www.r-project.org/ (accessed on 1 October 2019).

46. Oksanen, J.; Blanchet, F.G.; Friendly, M.; Kindt, R.; Legendre, P.; McGlinn, D.; Minchin, P.R.; O’Hara, R.B.; Simpson, G.L.; Solymos, P.; et al. Package ‘Vegan': Community Ecology Package. R Package Version 2.5-6. Available online: https://cran.r-project.org/package=vegan (accessed on 1 October 2019).

47. Hsieh, T.C.; Ma, K.H.; Chao, A. Package 'iNEXT' Interpolation and Extrapolation for Species Diversity. Version 2.0.19. 2019. Available online: https://cran.r-project.org/web/packages/iNEXT/index.html (accessed on 10 December 2019).

48. Kassambara, A. Package 'ggpubr'. 'ggplot2' Based Publication Ready Plots R package. R Package Version 0. 2. 4. Available online: https://cran.r-project.org/web/packages/ggpubr/ (accessed on 21 May 2019).

49. De Caceres, M.; Jansen, F. Package 'indicspecies': Relationship Between Species and Groups of Sites. Version 1.7. 6. 2016. Available online: https://cran.r-project.org/web/packages/indicspecies/index.html (accessed on 29 October 2019).

50. Hubbard, C.J.; Brock, M.T.; van Diepen, L.T.; Maignien, L.; Ewers, B.E.; Weinig, C. The plant circadian clock influences rhizosphere community structure and function. ISME J. 2018, 12, 400-410. [CrossRef]

51. Faust, K.; Raes, J. CoNet app: Inference of biological association networks using Cytoscape. F1000Research 2016, 5, 1519. [CrossRef]

52. Faust, K.; Sathirapongsasuti, S.; Izard, J.; Segata, N.; Gevers, D.; Raes, J.; Huttenhower, C. Microbial Co-occurrence Relationships in the Human Microbiome. PLoS Comput. Biol. 2012, 8, e1002606. [CrossRef]

53. Mandakovic, D.; Rojas, C.; Maldonado, J. Structure and co-occurrence patterns in microbial communities under acute environmental stress reveal ecological factors fostering resilience. Sci Rep. 2018, 8, 5875. [CrossRef]

54. Hodge, A.; Robinson, D.; Fitter, A. Are microorganisms more effective than plants at competing for nitrogen? Trends Plant Sci. 2000, 5, 304-308. [CrossRef]

55. Fierer, N.; Lauber, C.L.; Ramirez, K.S.; Zaneveld, J.; Mark, A.; Bradford, M.A.; Knight, R. Comparative metagenomic, phylogenetic and physiological analyses of soil microbial communities across nitrogen gradients. ISME J. 2012, 6, 1007-1017. [CrossRef] [PubMed]

56. Chen, D.; Lan, Z.; Hu, S.; Bai, Y. Effects of nitrogen enrichment on belowground communities in grassland: Relative role of soil nitrogen availability vs. soil acidification. Soil Biol. Biochem. 2015, 89, 99-108. [CrossRef]

57. Williams, A.; Manoharan, L.; Rosenstock, N.P.; Olsson, P.A.; Hedlund, K. Long-term agricultural fertilization alters arbuscular mycorrhizal fungal community composition and barley (Hordeum vulgare) mycorrhizal carbon and phosphorus exchange. New Phytol. 2017, 213, 874-885. [CrossRef] [PubMed] 
58. Allison, S.D.; Hanson, C.A.; Treseder, K.K. Nitrogen fertilization reduces diversity and alters community structure of active fungi in boreal ecosystems. Soil Biol. Biochem. 2007, 39, 1878-1887. [CrossRef]

59. Al-Hassan, R.; Poulton, C. Agriculture and Social Protection in Ghana. F.A.C. Working Paper 09; Future Agricultures Consortium: Brighton, UK, 2009.

60. Guo, J.H.; Liu, X.J.; Zhang, Y.; Shen, J.L.; Han, W.X.; Zhang, W.F.; Christie, P.; Goulding, K.W.T.; Vitousek, P.M.; Zhang, F.S. Significant Acidification in Major Chinese Croplands. Science 2010, 327, 1008-1010. [CrossRef]

61. Rodriguez, R.; Redman, R. More than 400 million years of evolution and some plants still can't make it on their own: Plant stress tolerance via fungal symbiosis. J. Exp. Bot. 2008, 59, 1109-1114. [CrossRef]

62. Hartman, K.; Tringe, S.G. Interactions between plants and soil shaping the root microbiome under abiotic stress. Biochem. J. 2019, 476, 2705-2724. [CrossRef]

63. Devictor, V.; Clavel, J.; Julliard, R. Defining and measuring ecological specialization. J. Appl. Ecol. 2010, 47, 15-25. [CrossRef]

64. Ghosh, S.; Ayayee, P.A.; Barrantes, O.J.V.; Blackwood, C.B.; Royer, T.V.; Leff, L.G. Initial nitrogen enrichment conditions determines variations in nitrogen substrate utilization by heterotrophic bacterial isolates. BMC Microbiol. 2017, 17, 87. [CrossRef] [PubMed]

65. Janda, J.M.; Abbott, S.L. The Genus Aeromonas: Taxonomy, Pathogenicity, and Infection. Clin. Microbiol. Rev. 2010, 23, 35-73. [CrossRef] [PubMed]

66. Kunda, P.; Dhal, P.K.; Mukherjee, A. Endophytic bacterial community of rice (Oryza sativa L.) from coastal saline zone of West Bengal: 16S rRNA gene-based metagenomics approach. Meta Gene 2018, 18, 79-86. [CrossRef]

67. Miyamoto, T.; Kawahara, M.; Minamisawa, K. Novel Endophytic Nitrogen-Fixing Clostridia from the Grass Miscanthus sinensis as Revealed by Terminal Restriction Fragment Length Polymorphism Analysis. Appl. Envirol. Microbiol. 2004, 70, 6580-6586. [CrossRef]

68. Xie, C.H.; Yokota, A. Pleomorphomonas oryzae gen. nov., sp. nov., a nitrogen-fixing bacterium isolated from paddy soil of Oryza sativa. Int. J. Syst. Evol. Microbiol. 2005, 55, 1233-1237. [CrossRef] [PubMed]

69. Mhedbi-Hajri, N.; Jacques, M.A.; Koebnik, R. Adhesion Mechanisms of Plant-Pathogenic Xanthomonadaceae. Adv. Exp. Med. Biol. 2011, 715, 71-89. [CrossRef] [PubMed]

70. Das, A.; Rangaraj, N.; Sonti, R.V. Multiple Adhesin-Like Functions of Xanthomonas oryzae pv. oryzae Are Involved in Promoting Leaf Attachment, Entry, and Virulence on Rice. Mol. Plant Microbe Interact. 2011, 22, 73-85. [CrossRef] [PubMed]

71. Naik, B.S.; Shashikala, J.; Krishnamurthy, Y.L. Study on the diversity of endophytic communities from rice (Oryza sativa L.) and their antagonistic activities in vitro. Mycol. Res. 2009, 164, 290-296. [CrossRef]

72. Fatima, M.; Khan, I.; Qazi, M.A.; Shahzadi, I.; Mumtaz, A.; Hashmi, M.A.; Khan, A.K.; Ismail, T. Chaetomium endophytes: A repository of pharmacologically active metabolites. Acta Physiol. Plant. 2016, 38, 136. [CrossRef]

73. Zhang, Y.; Crous, P.W.; Schoch, C.L.; Hyde, K.D. Pleosporales. Fungal Divers. 2011, 53, 1-221. [CrossRef]

74. Zhang, N.; Castlebury, L.A.; Miller, A.N.; Huhndorf, S.M.; Schoch, C.L.; Seifert, K.A.; Rossman, A.Y.; Rogers, J.D.; Kohlmeyer, J.; Volkmann-Kohlmeyer, B.; et al. An overview of the systematics of the Sordariomycetes based on a four-gene phylogeny. Mycologia 2006, 98, 1076-1087. [CrossRef] [PubMed]

75. Moreira, F.G.; dos Reis, S.; Costa, M.A.F.; de Souza, C.G.M.; Peralta, R.M. Production of hydrolytic enzymes by the plant pathogenic fungus myrothecium verrucaria in submerged cultures. Braz. J. Microbiol. 2005, 36, 7-11. [CrossRef]

76. Islam, M.S.; Haque, M.S.; Islam, M.M.; Emdad, E.M.; Halim, A.; Hossen, Q.M.M.; Hossain, M.Z.; Ahmed, B.; Rahim, S.; Rahman, M.S.; et al. Tools to kill: Genome of one of the most destructive plant pathogenic fungi Macrophomina phaseolina. BMC Genom. 2012, 13, 493. [CrossRef] [PubMed]

77. Deveau, A.; Bonito, G.; Uehling, J.; Paoletti, M.; Becker, M.; Bindschedler, S.; Hacquard, S.; Herv'e, V.; Labb'e, J.; Lastovetsky, O.A.; et al. Bacterial-fungal interactions: Ecology, mechanisms and challenges. FEMS Microbiol. Rev. 2018, 42, 335-352. [CrossRef]

78. Stopnisek, N.; Zühlke, D.; Carlier, A.; Barberán, A.; Fierer, N.; Becher, D.; Riedel, K.; Eberl, L.; Weisskopf, L. Molecular mechanisms underlying the close association between soil Burkholderia and fungi. ISME J. 2016, 10, 253-264. [CrossRef] [PubMed] 
79. Cugini, C.; Calfee, M.W.; Farrow, J.M.; Morales, D.K.; Pesci, E.C.; Hogan, D.A. Farnesol, a common sesquiterpene, inhibits P.Q.S. production in Pseudomonas aeruginosa. Mol. Microbiol. 2007, 65, 896-906. [CrossRef] [PubMed]

80. De Boer, W. Upscaling of fungal-bacterial interactions: From the lab to the field. Curr. Opin. Microbiol. 2017, 37, 35-41. [CrossRef]

81. Van Overbeek, L.S.; Saikkonen, K. Impact of Bacterial-Fungal Interactions on the Colonization of the Endosphere. Trends Plant Sci. 2016, 21, 230-242. [CrossRef]

82. Singh, B.K.; Nunan, N.; Ridgway, K.P.; McNicol, J.; Young, J.P.W.; Daniell, T.J.; Prosser, J.I.; Millard, P. Relationship between assemblages of mycorrhizal fungi and bacteria on grass roots. Enviol. Microbiol. 2008, 10, 534-541. [CrossRef]

83. Cheung, M.K.; Wong, C.K.; Chu, K.H.; Kwan, H.S. Community Structure, Dynamics and Interactions of Bacteria, Archaea and Fungi in Subtropical Coastal Wetland Sediments. Sci. Rep. 2018, 8, 14397. [CrossRef]

(C) 2020 by the authors. Licensee MDPI, Basel, Switzerland. This article is an open access article distributed under the terms and conditions of the Creative Commons Attribution (CC BY) license (http://creativecommons.org/licenses/by/4.0/). 